\title{
Improved compliance and increased intake of energy and protein with a high energy density, low volume multi-nutrient supplement
}

\author{
G. P. Hubbard ${ }^{1}$, B. Buchan ${ }^{2}$, K. Sanders ${ }^{3}$, S. Brothers ${ }^{3}$ and R. J. Stratton ${ }^{1}$ \\ ${ }^{1}$ Medical Affairs, Nutricia, Wiltshire BA14 OXQ, UK, ${ }^{2}$ Southern Cross Healthcare, County Durham DL3 6AH, UK and \\ ${ }^{3}$ Dietetics Department, University Hospital Lewisham, London SE13 6LH, UK
}

\begin{abstract}
Although it is often hypothesised that higher energy density liquid supplements will have a greater effect on total nutritional intake than standard supplements, there have been few comparative studies in clinical settings ${ }^{(1)}$. This study aimed to compare the effects of a low volume, high energy density $(2.4 \mathrm{kcal} / \mathrm{ml})$ liquid oral nutritional supplement (ONS) versus standard ONS $(1.5-2.0 \mathrm{kcal} / \mathrm{ml})$ on food and total energy and protein intakes and patients' compliance with supplementation.

A longitudinal study was carried out in patients at risk of malnutrition requiring an oral nutritional supplement in three care homes and four hospitals in the UK and the Netherlands. Thirty eight patients (mean age 80 years (SD 15), $68 \%$ female, mean BMI $17.9 \mathrm{~kg} / \mathrm{m}^{2}$ (SD 4.3), $55 \%$ in care homes, $45 \%$ in hospitals) completed the study and were eligible for analysis. Patients were offered a range of standard $200 \mathrm{ml}$ ONS $(1.5-2.0 \mathrm{kcal} / \mathrm{ml}, 300-400 \mathrm{kcal}$ and $11-20 \mathrm{~g}$ protein per $200 \mathrm{ml}$ bottle) ad libitum, daily in addition to the diet for 3 days. Patients were then offered a higher energy density, low volume ONS $(2.4 \mathrm{kcal} / \mathrm{ml}, 300 \mathrm{kcal}, 12 \mathrm{~g}$ protein per $125 \mathrm{ml}$ bottle, Fortisip Compact, Nutricia ${ }^{\mathbb{R}}$ ) ad libitum daily in addition to the diet for a mean of 4 days (range 3-5 days). During the two periods of supplementation, dietary intake, including the intake of all foods, drinks and supplements were recorded on one day using $24 \mathrm{~h}$ food record charts (analysed using WISP version 3.0 dietary analysis package; Tinuviel, Anglesey, UK). Patients' compliance with ONS consumption (mean \% bottle consumed) was recorded on a daily basis throughout the study.

Total energy intake (diet plus ONS) was significantly greater when consuming the higher energy density $(2.4 \mathrm{kcal} / \mathrm{ml})$ ONS compared to standard ONS $(+200 \mathrm{kcal} / \mathrm{d}, P=0.01$, see table). The mean intake of energy from $2.4 \mathrm{kcal} / \mathrm{ml}$ ONS was significantly greater $(30 \%)$ than the intake from standard ONS $(P=0.002$, see table). Total protein intake (diet plus ONS) was significantly higher with the $2.4 \mathrm{kcal} / \mathrm{ml}$ ONS compared to standard ONS $(+11 \mathrm{~g} / \mathrm{d}, P=0.005$, see table). The mean intake of protein from the $2.4 \mathrm{kcal} / \mathrm{ml}$ ONS was significantly greater $(24 \%)$ than the intake from standard ONS $(P=0.004$, see Table). Voluntary dietary intakes (diet only) were similar during both periods of supplementation (see Table).
\end{abstract}

\begin{tabular}{|c|c|c|c|c|c|c|}
\hline & \multicolumn{3}{|c|}{ Energy $(\mathrm{kcal} / \mathrm{d})$} & \multicolumn{3}{|c|}{ Protein $(\mathrm{g} / \mathrm{d})$} \\
\hline & Standard ONS & $2.4 \mathrm{kcal} / \mathrm{ml} \mathrm{ONS}$ & $P^{*}$ & Standard ONS & $2.4 \mathrm{kcal} / \mathrm{ml} \mathrm{ONS}$ & $P^{*}$ \\
\hline Diet and ONS & $1651(612)$ & $1851(630)$ & 0.01 & $68(29)$ & $79(31)$ & 0.005 \\
\hline Diet only & $1144(556)$ & $1190(634)$ & 0.524 & 47 (27) & $53(31)$ & 0.134 \\
\hline ONS only & $507(286)$ & $661(348)$ & 0.002 & $21(12)$ & $26(14)$ & 0.004 \\
\hline
\end{tabular}

*Paired samples $t$-test.

Overall mean percentage compliance throughout the study period was significantly higher with the $2.4 \mathrm{kcal} / \mathrm{ml}$ ONS (91\%) than with standard ONS $(77 \%)(P=0.0001$, paired samples $t$-test $)$.

This longitudinal study suggests that compliance is significantly greater with a more energy dense $(2.4 \mathrm{kcal} / \mathrm{ml})$, low volume liquid ONS than standard energy density supplements, resulting in patients consuming significantly greater total energy and protein intakes. Further well-designed, randomised trials are warranted to examine the clinical benefits of higher energy density low volume supplements.

Thanks to the staff and patients involved in this study at Addenbrookes Hospital, Cambridge; The Royal Gwent Hospital, Newport; University Hospital Lewisham, London; Great Western Hospital, Swindon; Merlin Court Care Home, Marlborough; Ravenscroft Care Home, Trowbridge and Siloam Care Home, the Netherlands.

1. Stratton RJ, Green CJ \& Elia M (2003) Disease-Related Malnutrition: An Evidence-Based Approach. Oxford: CABI Publishing. 